\title{
BACK ANALYSIS OF OSTERBERG-CELL PILE LOAD TEST BY MEANS OF THREE-DIMENSIONAL GEOTECHNICAL MODELING
}

\author{
Szilárd Kanizsár \\ Multidisciplinary Doctoral School of Engineering Sciences, Széchenyi István \\ University, Györ, Egyetem tér 1., H-9026, Hungary; kanizsar@t-online.hu
}

\begin{abstract}
In 3D geotechnical modelling it is essential for the realistic simulation of soil behavior that the parameters of the hardening soil with small strain constitutive model are specified appropriately. The possibility of deriving these parameters for very stiff cohesive soils similar to the so called Kiscell clay that has a significant role in deep construction projects in Budapest, from laboratory and field tests is rather limited. The results of the pile load test completed for the MOL Campus high-rise building project proved to be useful data source. The article presents the circumstances of the quoted Osterberg-cell pile load tests and the modelling of the pile performed by the above-mentioned soil model. The parameters specified on the basis of laboratory tests - and in absence of those based on literature - data can be fine-tuned by approaching the load test results.
\end{abstract}

\section{KEYWORDS}

Geotechnical modeling, Kiscell clay, Plaxis 3D, Soil material model, Pile load test

\section{INTRODUCTION}

The landscaping regulations that are currently in force indicate two areas for tower buildings of $120 \mathrm{~m}$ height. One of them is on the northern edge of Csepel Island (Budapest XXI. district), while the other is near Kopaszi Dam (Budapest, XI. district), where the first high-rise building is currently under construction. The office complex named "MOL-Campus" will consist of a $120 \mathrm{~m}$ high, 28-storey tower and the adjoining 6-storey "podium" building, with a 4-level underground parking lot underneath. The foundation of the tower building was constructed as a CPRF (combined pile raft foundation) structure, the loads of the building are transferred to the subsoil partially by the typically $2.2 \mathrm{~m}$ thick reinforced concrete foundation slab and the $135 \mathrm{pcs}$ of $1.20 \mathrm{~m}$ diameter bored piles. The foundation is confined in a watertight manner by means of a diaphragm wall, the temporary dewatering during construction was ensured by the Kiscell clay constituting the bedrock of the area and temporary drainage wells. The final drainage of the building is provided by the seepage system constructed under the foundation slab. The podium building was constructed on reinforced concrete raft foundation.

For the design of the CPRF structure a test pile had previously been bored. This - differently from the traditional reaction beam layout - was carried out by implementing the so-called O-cell (Osterberg-cell) technique. The aim of the load test was so that its results would provide values for the shaft friction and base resistance of the piles of the foundation structure. 3D modeling was performed related to the CPRF structure and the test pile by means of PLAXIS 3D geotechnical software, the results of which were published [1]. In this finite element model the Kiscell clay with its stiff, rock-like behavior was described by the Mohr-Coulomb soil model selected on the basis of more considerations. As an enhancement to the modeling, the newer model of the pile load test was also prepared in relation to the Kiscell clay, using the more advanced HSS (hardening soil with small strain stiffness) soil model. This possibility among all enables to take into consideration over- 
consolidation, deformation moduli depending on stress level and greater stiffness acknowledged in the range of initial and small deformations.

Certain parameters related to the Kiscell clay could not be determined either from field or laboratory tests. The determination of these was among the aims of the research. Once the building is structurally complete and the settlement data is available, the validation and - if required - the correction of the parameters of the HSS soil model of the Kiscell clay and of the entire geotechnical model of the building will be enabled.

\section{METHOD OF THE MODELING}

\section{Soil environments}

On the basis of the borings in the vicinity of the test pile, soil stratification outlined in Figure 1. is to be considered. Due to quantity restrictions, there is no possibility for the detailed outlining of the layers located above the Kiscell clay, their parameters are included in Table 1.

The Kiscell clay appears in the depth of $18.5 \mathrm{~m}$ under the surface. It must be noted, however, that this depth is only valid in the vicinity of the borehole near the test pile, the clay surface related to the entire area shows an inclination moving away from the Danube. On the basis of the plasticity index $\left(I_{p}=15-25 \%\right)$ the clay can be regarded as low-medium plasticity clay. Resulting from its low water content $(\mathrm{w}<10 \%)$ and high consistency index $\left(I_{c}=1.4-1.5\right)$, it can be classified as hard. According to tests related to permeability $\left(k=(3 \div 5) \cdot 10^{-12} \mathrm{~m} / \mathrm{s}\right)$, it can be regarded as watertight. Figure 2. presents the soil samples of the Kiscell clay taken at depth of $\sim 20 \mathrm{~m}$.

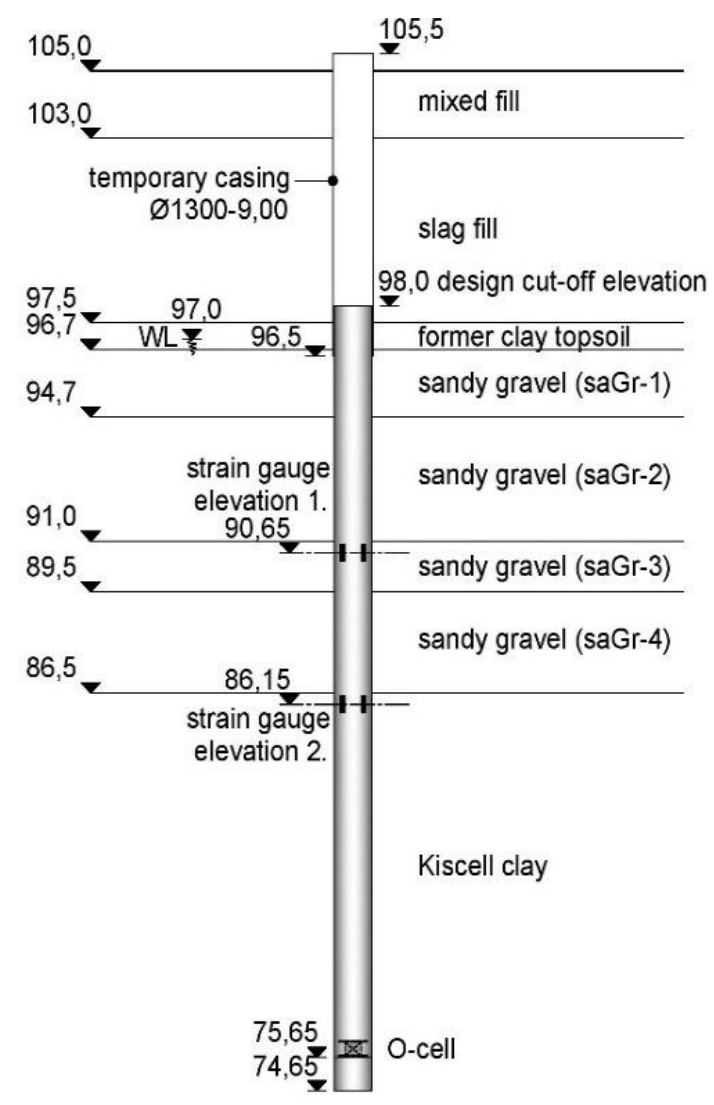

Fig. 1 - Stratification 
Article no. 51

CIVIL

ENGINEERING

JOURNAL

THE CIVIL ENGINEERING JOURNAL 3-2021

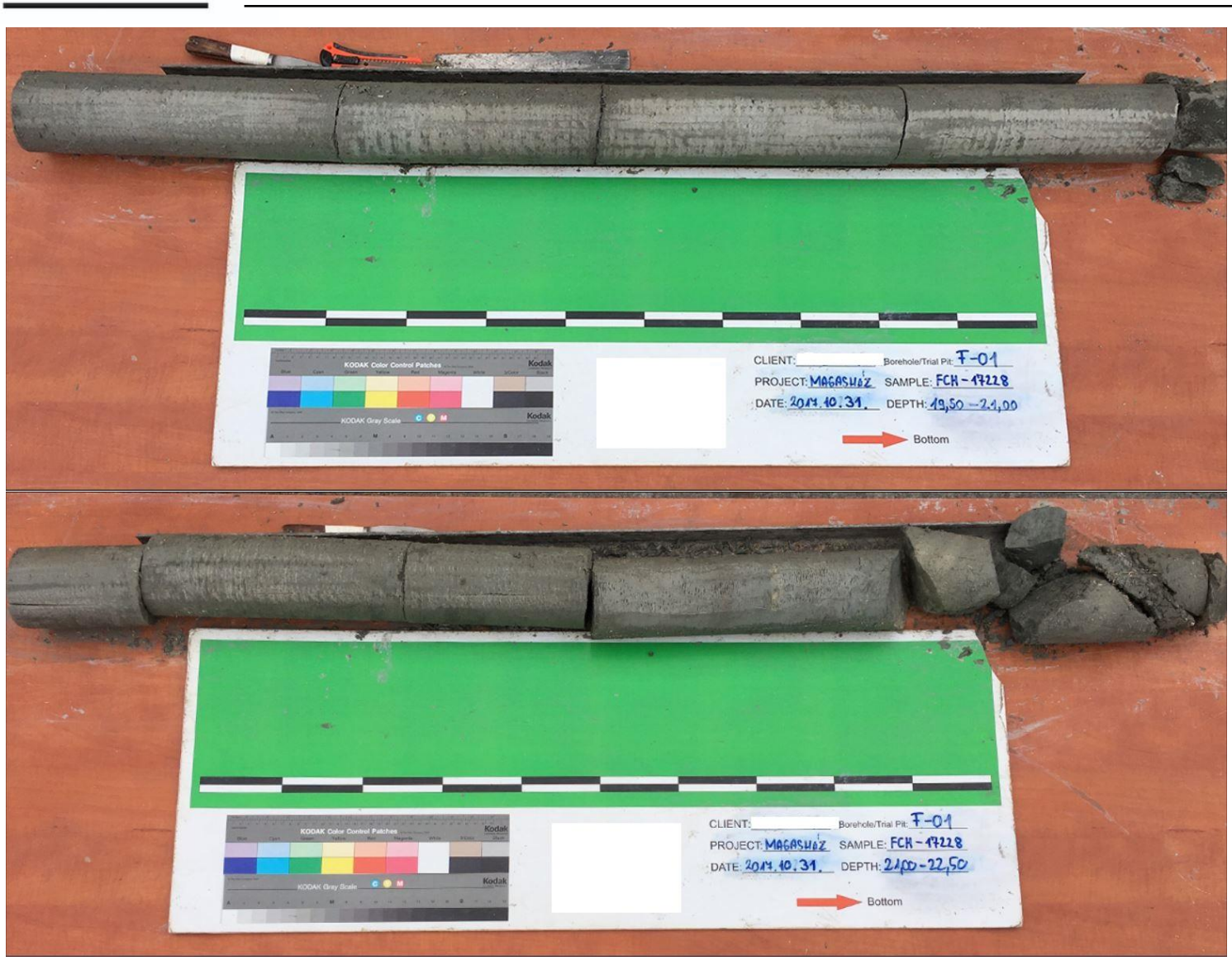

Fig. 2 - Core samples from the top zone of the Kiscell clay layer

Tab. 1: Model parameters of soil layers

\begin{tabular}{|c|c|c|c|c|c|c|c|c|c|}
\hline model parameter & : & 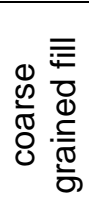 & $\begin{array}{l}\bar{\equiv} \\
\text { 票 } \\
\omega\end{array}$ & 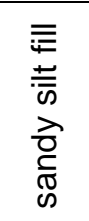 & 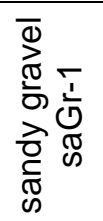 & 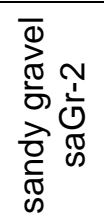 & 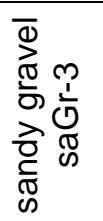 & 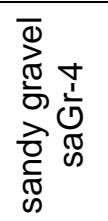 & 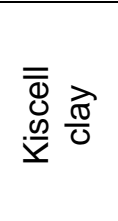 \\
\hline natural unit weight $\left(\gamma_{n}\right)$ & $\mathrm{kN} / \mathrm{m}^{3}$ & 17,0 & 17,0 & 18,0 & 20,0 & 21,0 & 20,0 & 21,5 & 23,0 \\
\hline saturated unit weight $\left(\gamma_{t}\right)$ & $\mathrm{kN} / \mathrm{m}^{3}$ & 18,0 & 18,0 & 19,0 & 20,0 & 21,1 & 20,0 & 21,5 & 23,0 \\
\hline initial void ratio (e enit $)$ & - & 0,80 & 0,80 & 0,70 & 0,65 & 0,50 & 0,65 & 0,4 & 0,3 \\
\hline internal friction angle $\left(\phi^{\prime}\right)$ & ${ }^{\circ}$ & 28 & 24 & 22 & 31 & 31 & 31 & 31 & 28 \\
\hline cohesion (c) & $\mathrm{kPa}$ & 1 & 1 & 5 & 1 & 1 & 1 & 1 & var \\
\hline dilatation angle $(\psi)$ & & 0 & 0 & 0 & 10 & 10 & 10 & 10 & - \\
\hline undrained shear strength $(\mathrm{su})$ & $\mathrm{kPa}$ & - & - & - & - & - & - & - & 951 \\
\hline oedometric modulus ( $\mathrm{E}_{\mathrm{oed}} \mathrm{ref}^{\text {ref }}$ & $\mathrm{MPa}$ & 33,0 & 9,5 & 5,1 & 16,9 & 26,9 & 14,3 & 26,9 & var \\
\hline Poisson-ratio $(v)$ & - & - & - & - & - & - & - & - & 0,2 \\
\hline reload modulus (Euref) & $\mathrm{MPa}$ & 99,0 & 28,5 & 15,3 & 50,0 & 90,0 & 50,0 & 80,0 & var \\
\hline dev. elastic modulus ( $E_{50}$ ref) & $\mathrm{MPa}$ & 33,0 & 9,5 & 5,1 & 16,9 & 26,9 & 14,3 & 26,9 & var \\
\hline exp. of hardening function (m) & - & 0,6 & 0,8 & 0,8 & 0,5 & 0,5 & 0,5 & 0,5 & 1,0 \\
\hline initial shear modulus ( $\left.\mathrm{G}_{0}^{\text {ref }}\right)$ & $\mathrm{MPa}$ & 95,6 & 61,9 & 53,0 & 108,7 & 153,7 & 101,9 & 211,6 & var \\
\hline shear strain $\left(\gamma_{0,7}\right)\left[\cdot 10^{-4}\right]$ & - & 1,0 & 1,0 & 1,0 & 2,3 & 2,6 & 2,4 & 2,9 & var \\
\hline permeability (k) & $\mathrm{m} / \mathrm{s}$ & $10^{-3}$ & $10^{-3}$ & $10^{-5}$ & $10^{-6}$ & $10^{-6}$ & $10^{-6}$ & $10^{-6}$ & $4 \cdot 10^{-12}$ \\
\hline over-consolidation ratio (OCR) & & & - & - & - & - & & & var \\
\hline
\end{tabular}




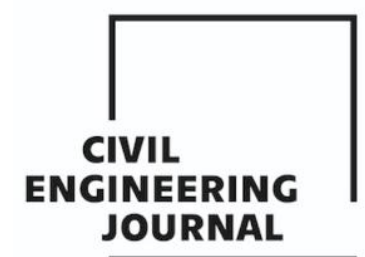

Article no. 51

THE CIVIL ENGINEERING JOURNAL 3-2021

The groundwater typically saturates in the sandy gravel layers, its level is controlled by the actual water level of the Danube, which is located nearby. The groundwater level observed at the time of the construction of the test pile was in the depth of $8 \mathrm{~m}$ below the construction platform. The model parameters deriving from the results of the laboratory tests performed on the soil layers and those estimated are included in Table 1.

The non-measured parameters and those that were measured but clearly had greater uncertainties had not previously been set, their determination was the task of the modeling. These parameters are included in the table with the indication var (variable).

\section{Layout and loading of the test pile}

\section{Description of the O-cell pile load test}

In comparison to the traditional, reaction beam pile load test, the O-cell technology does not require anchoring piles to provide the reaction forces. One or more single-use hydraulic loading unit, the $\mathrm{O}$-cell is installed in the pile to be loaded at a certain depth or even in more than one depth levels. The position of O-cell/cells shall be determined so that the characteristics of the toe resistance and skin resistance of the pile and the curves of the specific skin frictions mobilized in typical layers shall be determined from the displacements originating from the loads. Rationally, it must also be observed that for the exhaustion of the resistances arising on single pile sections those arising on other parts of the pile shall provide sufficient resistance. In the simplest case, the toe resistance and the skin friction of the pile can be separated by means of the cell located in the immediate vicinity of the toe presuming that they are essentially of the same magnitude.

Due to the hydraulic pressure in the O-cell, the cell starts to open along the pile axis and forces of opposite directions transferred on its bottom and top plains to displace the pile section under the cell downwards and the pile section above the cell upwards. If the cell is immediately above the toe, the displacement of the bottom part is practically determined by the toe resistance, whereas the top part is determined by the skin friction and the elastic compression of the pile. Since the toe resistance of the bottom part and the skin resistance of the top part balance each other, the loading can only be carried on until the ultimate value of either bearing capacity component is reached. Consequently, no direct information is available on the ultimate value of failure resistance of the stronger part.

\section{Construction and instrumentation of the test pile}

The test pile at MOL Campus was constructed with a $1200 \mathrm{~mm}$ nominal diameter in a location outside but in the vicinity of the diaphragm wall enclosed area. The pile was bored from the original $105.00 \mathrm{maBSI}$ (meter above Baltic Sea level) terrain level following the installation of a $\varnothing 1300 \mathrm{~mm}$, $8.65 \mathrm{~m}$ long guide tube casing, by means of auger and drum tools using fluid support protection. The borehole following the cleaning of the toe, the change of the slurry and the installation of the reinforcement cage was concreted between the 74.65 maBSI toe level and the $98.00 \mathrm{maBSI}$ designed trim back level.

The pile was loaded using a $540 \mathrm{~mm}$ diameter, $12.9 \mathrm{MN}$ O-cell unit, which had previously been positioned and installed into the reinforcement cage $1.00 \mathrm{~m}$ above the pile toe. Thus the 23.35 $\mathrm{m}$ long pile was divided by the O-cell into a $22.35 \mathrm{~m}$ long top part and a $1.00 \mathrm{~m}$ long bottom toe section. The displacements of the $\mathrm{O}$-cell were measured by four installed displacement gauges. Two pairs of strain gauges were installed at two levels in the top pile section, which when measuring deformation as a result of the normal force provide data for the determination of the change of specific shaft resistances. The elastic compression of the pile was measured by means of the installed indication rods. For the measurements a reference holder set up on the terrain level and 


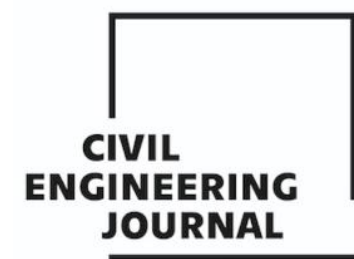

Article no. 51

THE CIVIL ENGINEERING JOURNAL 3-2021

displacement gauges installed on it were used. The displacements of the pile were corrected by the movement of the reference holder.

\section{Measurement results of the test pile}

\section{Resistance of the top part}

The resistance of the top part is provided by the skin friction. For the determination of the net load acting upon the pile from the load operated by the cell for the top section the counterforce shall be deducted, the value of which is $0.36 \mathrm{MN}$. Ignoring the last three load steps due to the abovementioned reasons, the displacement of the top section was $55.97 \mathrm{~mm}$ due to the $12.34 \mathrm{MN}$ force (11.98 MN net load). It is worth taking into consideration the measurement data describing the relationship between the force and the displacement for the modeling up to this point as the unconsolidated displacements measured in the last three steps are probably smaller than the actual ones.

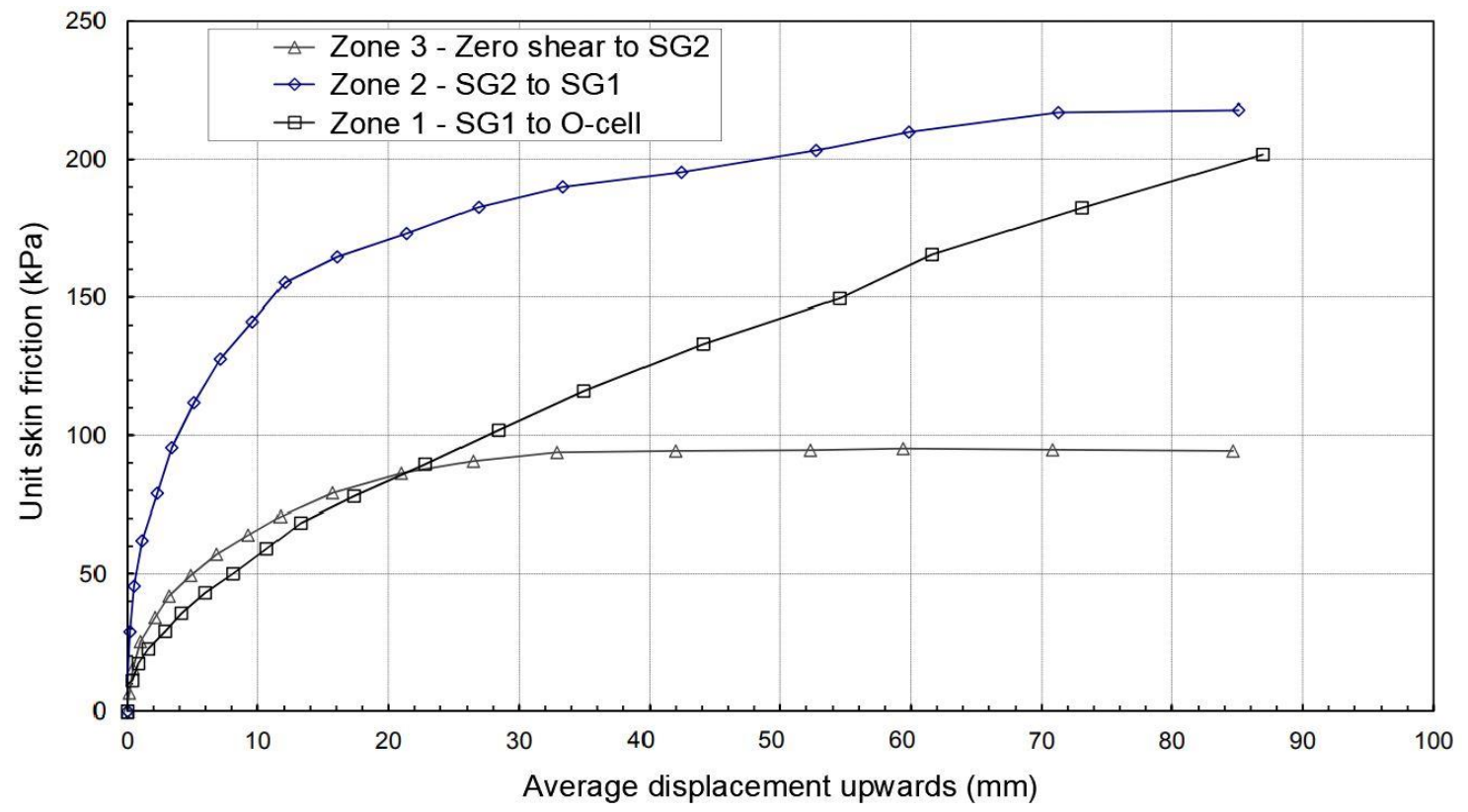

Fig. 3 - Mobilized specific shaft resistances

The strain gauges set up on two levels divided the shaft along its length into three zones. The increase of specific shaft resistance values could be determined for each zone and it was striking that their characteristics significantly differ. The curves related to individual zones are indicated in Figure 3.

The resistance of the top part is constituted by two values. One is the rigid body displacement of the pile, the other is its elastic compression. It results from the curves of Figure 3 . that the characteristics of the load-displacement are determined by the behavior typical of zones 2 and 3 . In accordance with the above, the load-displacement curve of the top section (Fig. 4.) does not follow the classic shape of Zone 1, but similar to curves characterizing zones 2 and 3 , it demonstrates that increasing forces are related to the increasing displacements in the range under investigation.

\section{Resistance of the bottom part}

The displacement of the bottom section is fundamentally a rigid body displacement as in relation to it the amount of the elastic compression can be ignored due to the small length. Ignoring the last three load steps, the displacement of the top section was $51.54 \mathrm{~mm}$ due to the $12.34 \mathrm{MN}$ force, which is similar to that of the top section. The characteristics of the toe resistance, which is entirely determined by the Kiscell clay, cannot be regarded as typical (Figure 4). The curve includes 
an inflexion point at the load that belongs to it a certain degree of stiffening might be experienced for greater forces. The displacements do increase due to the increasing load but at a slightly smaller rate than before. This is a contrary behavior to what is common. No direct explanation can be traced in the measurement data, however, the displacement gauges of the O-cell and the strain gauges both indicated some anomaly, which might refer to uneven force transfer and eccentricity. (It might also arise that the initial greater displacements derive from the compression of the soil that was slightly loosened at the base of the boring and of the settled slurry.) Certainly, the modeling of the inflexion curve could not have been the aim, only the approximation of the curve with the least deviation.

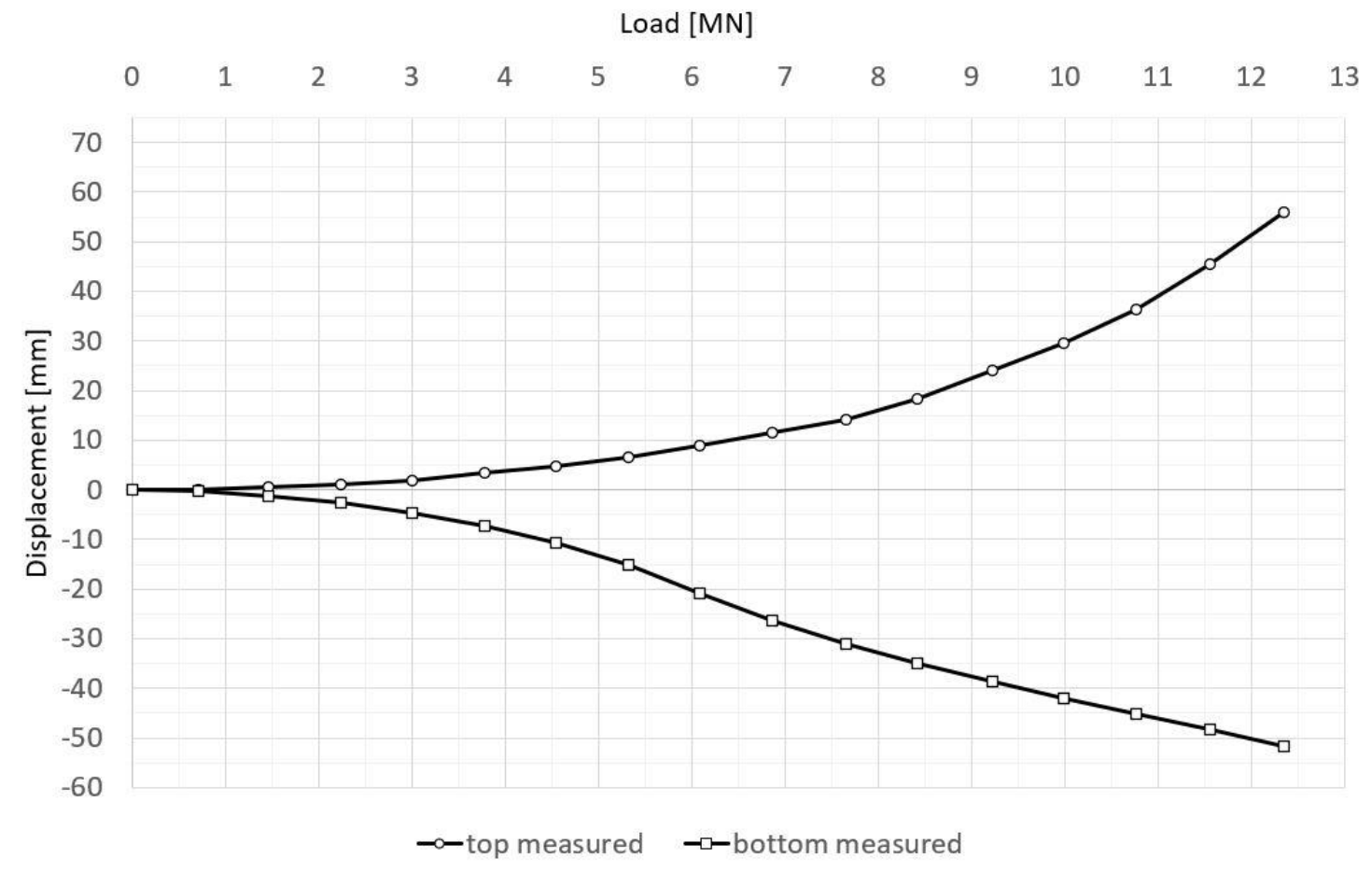

Fig. 4 - Load test curves of top and bottom parts

\section{Modeling of the pile load test}

\section{Model formation}

The 3D finite element model of the test pile was constructed in the Plaxis 3D software (Figure 5.). By taking into consideration the dimensions of the pile, a layered soil-block of $20 \times 20 \mathrm{~m}$ layout and $40 \mathrm{~m}$ depth modelled the bedding medium, which was ensured by the distance from its limit surfaces from the pile so that the model boundaries could not influence the results.

The model of a $1.20 \mathrm{~m}$ nominal diameter $23.35 \mathrm{~m}$ long pile was constituted by tetrahedron volume elements with 10 nodes. 


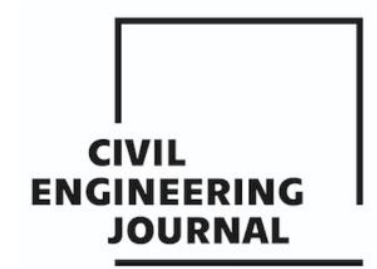

Article no. 51

THE CIVIL ENGINEERING JOURNAL 3-2021

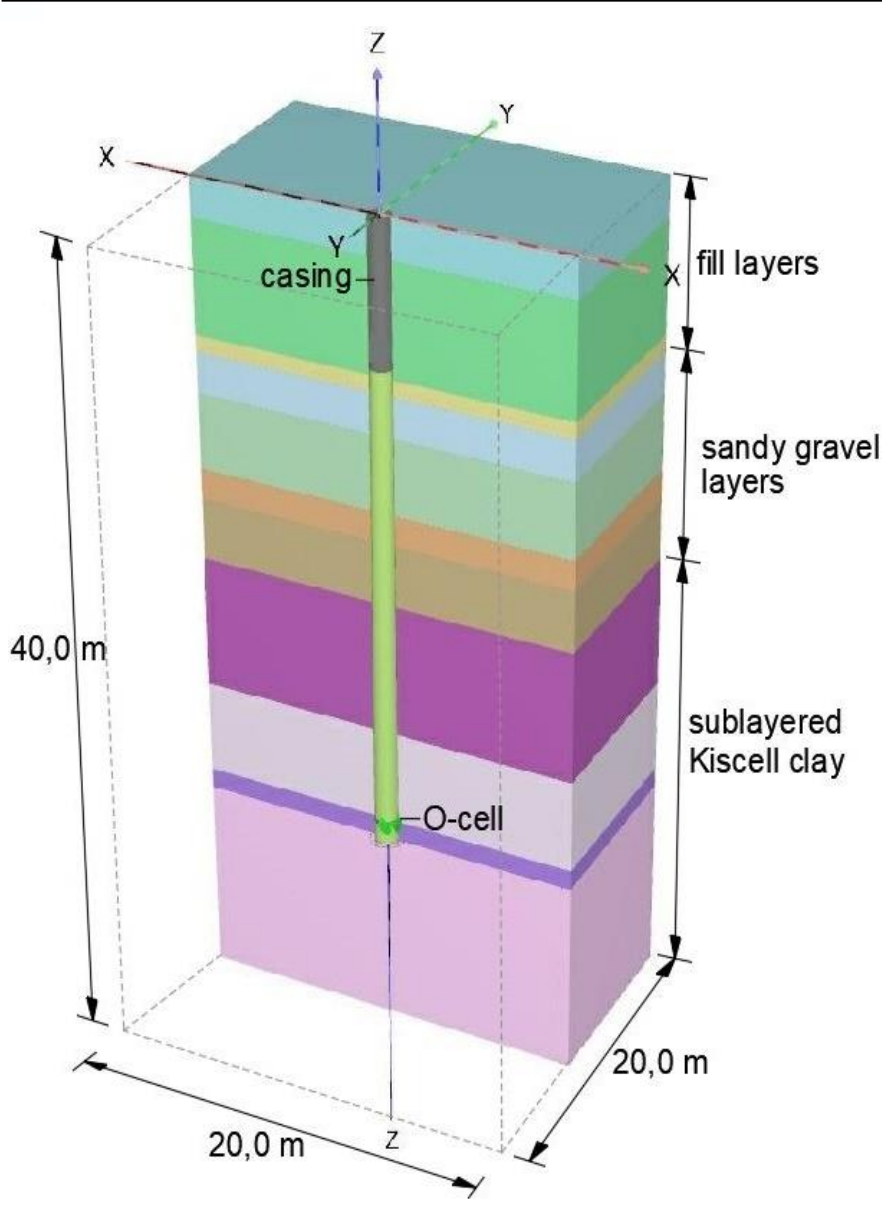

Fig. 5 - Model of O-cell pile load test

The special details of the test pile got unique attention, therefore, the realistic description of these is very important in the behavior of the entire model. These details are the casing, the O-cell, the interface elements simulating the relationship between the soil and the structure, the characteristics of the fresh concrete and the modeling technological aspects of the over-consolidation of the Kiscell clay.

The installation of the casing is a preliminary step that must be modelled as it also has a role in supporting the soil above the trim back level plain and the simulation of the stress state preceding the load. Its material and geometry can directly be modelled.

The modeling of the O-cell is a cardinal issue (Figure 6.) since this structure divides the pile in two and loads them immediately. The results that had been stated and published in Tschuchnigg's [2] PhD dissertation were taken into account at the modeling. The extension of the O-cell and thus the contrary movements of the two pile sections must be modelled in a way that the cell located between the pile sections shall represent materialistic continuity just like in reality but the volume elements of the neighboring soil could not "enter" the hole expanding due to the loading as a result of horizontal soil stresses. This for example might be achieved by means of the modeling of the steel membrane with orthotropic characteristics, which is located between the loading plates of the O-cell. In order to eliminate any load uptake by the membrane, its vertical stiffness was selected to be practically zero. Also, the prescribed displacement required for vertical elements shall be operated along the membrane surface, the value of which is also zero. It ensures that the steel "collar" is able 


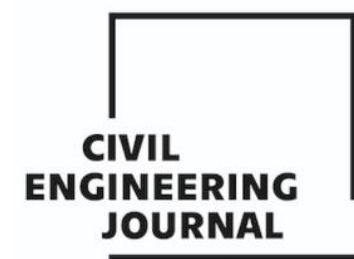

Article no. 51

THE CIVIL ENGINEERING JOURNAL 3-2021

to follow the opening-closing axial movement of the O-cell. However, for radial forces on the pile axis it behaves stiffly, supporting the neighboring soil elements.
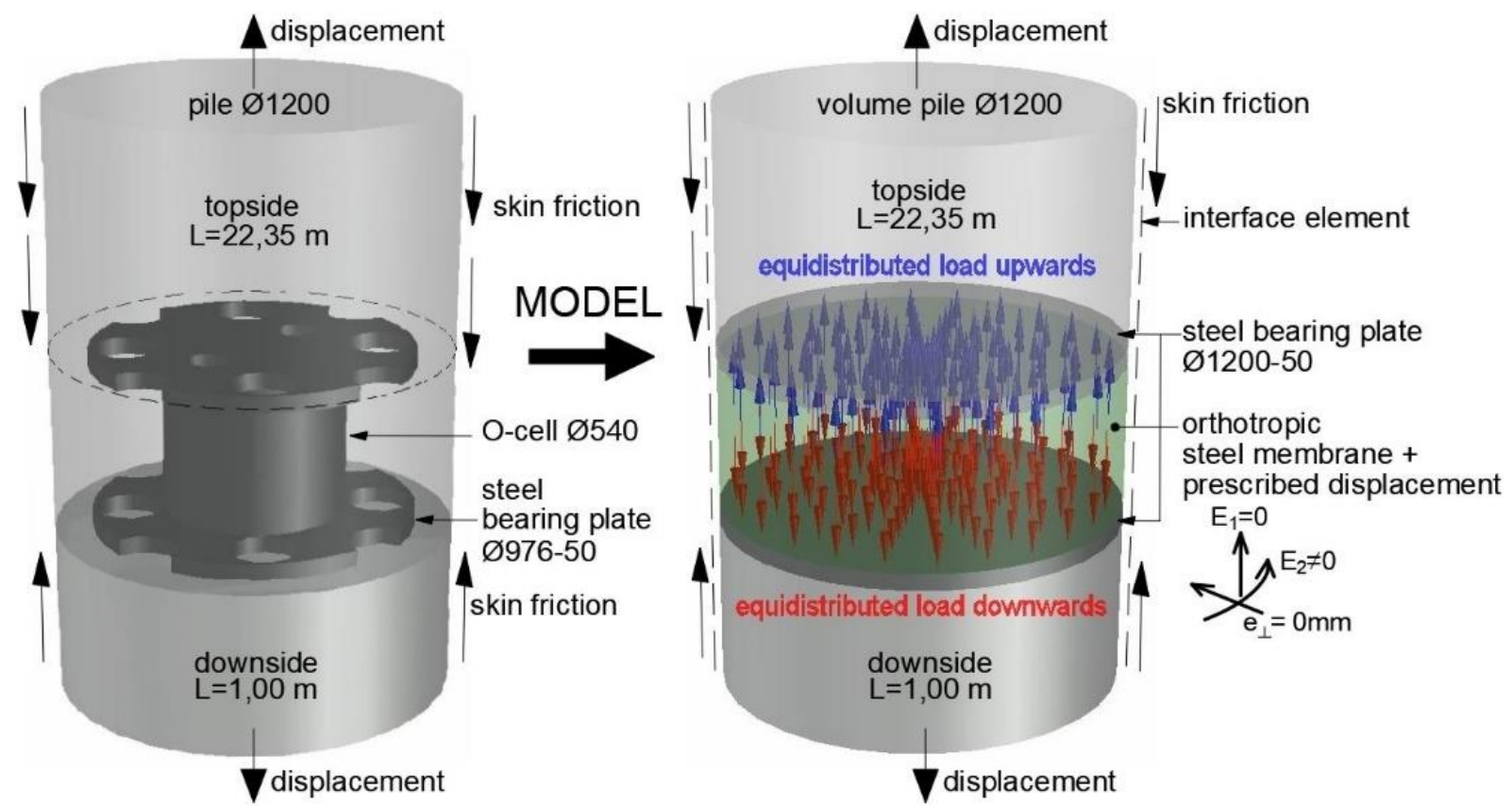

Fig. 6 - Model of O-cell

The relative displacement of the soil and the pile might be ensured by the use of interface elements. The ratio ( $\left.R_{\text {inter }}\right)$ serving for the quantification of the interaction can be set to be proportional to the shear strength of the soil being in contact with the pile. This also means that for the explored layers along the shaft different $R_{\text {inter }}$ values shall be provided. Besides the shaft surface the relative displacement must also be allowed along the toe surface. Since the shaft surface and the toe level of the bottom section are in the same Kiscell clay, the interactions under the toe and along the shaft cannot be modelled with the same $R_{\text {inter }}$ set value. There are two different mechanisms in which the rate of displacements significantly differs. The $\mathrm{cm}$ magnitude relative vertical displacement forming along the shaft and the $\mathrm{mm}$ magnitude horizontal displacement of the soil moving out of the loaded zone laterally under the toe shall be handled separately from modeling aspects. A part of the shaft of the top section is located in the Kiscell clay just like the shaft of the bottom section. As their displacements are nearly identical due to the identical loads, the specific shear strength is mobilized on the shaft surfaces in a similar scale. On the basis of the above, it is reasonable to relate the same $R_{\text {inter }}$ value for the shaft sections. Since the shaft surface of the pile boreholes deepened in the very stiff $\left(I_{c} \approx 1.5\right)$ Kiscell clay - in accordance with information gained on the excavated pile walls - is characterized by a texture that is very smooth (near glass), which in this case also had a bentonite „lubrication”, the value $R_{\text {inter }} \approx 0.15$ applied during the modeling shall be regarded as realistic. In order that different $R_{\text {inter }}$ values could be provided for the toe surface and shaft surface of the bottom section, the Kiscell clay had to divided in two sublayers in the plain of the toe. Their parameters are all identical, apart from the $R_{\text {inter }}$ values. With this technique, different $R_{\text {inter }}$ values might be set for the pile toe and pile shaft operating in the same soil.

At the concreting of the pile bore it is reasonable to take the liquid state of the concrete into account as until it sets it only acts as a loading medium for the soil zone around the borehole to reach its stress state prior to the loading. Therefore, during the modeling, in the piling phase, 
regarding its material the application of the elastoplastic concrete soil model was justified, with time dependent strength, stiffness and plasticity characteristics.

Another essential question is the consideration of over-consolidation of the Kiscell clay. In the HSS soil model this might be realized by providing the OCR (over-consolidation ratio) or POP (pre-overburden pressure) stress, the latter of which is also known as OCD (over-consolidation difference). The modeling of the load test was completed by providing the OCR values, which were available from the laboratory test results published by Józsa [3] regarding the over-consolidation. The soil samples were taken of the boreholes deepened for metro line M4. For the estimation of the pre-consolidation stress Józsa set up some connections regarding the Kiscell clay located on the Buda side (Kelenföld, Lágymányos) by using the results of the oedometric and triaxial tests ( $\mathrm{E}_{\mathrm{oed}}$ and $E_{u r}$ ). According to this publication, the OCR values that are hyperbolically connected to depth, fall between 1.5 and 4.5 from the connection set up by means of the oedometric modulus, whereas on the basis of the connection determined from the unloading-reloading modulus, the values range between 2.0 and 4.6. During the modeling the OCR ratio changing by depth might be taken into consideration with division to sublayers. The bottom of the sublayers is $-25,-30$ and $-40 \mathrm{~m}$ counting from terrain level regarded as zero. The average OCR values determined for the three sublayers are $3.5,3.0$ and 2.5 , respectively.

The modeling follows the entire process of the pile load test, from the preparation of the boring until the last load step. For this the following phases had to be defined in the finite element software:

Step 1: initial conditions and stress state

Step 2: boring of the casing

Step 3: pile boring, concreting, setting of the concrete

Step 4: activation of O-cell with $1.51 \mathrm{MN}$ force

Step 5: unloading of O-cell, zeroing the displacements

Step 6-21: O-cell loading in 16 steps up to the force of $12.34 \mathrm{MN}$.

\section{Initial parameters}

The values of modeling parameters that are required for the application of the HSS soil model are included in Table 1. No fixed values are included in the table for certain parameters of the Kiscell clay that bear uncertainty greater than usual. Concerning the above, it is worth starting from the value ranges derived from the statistic processing of previous laboratory tests and their precision, their values considered the most favorable are provided by the modeling output calibrated on the basis of the pile load test results. The values of the parameters will be outlined in the following:

- compression modulus: $E_{\text {oedinit }}=150 \div 250 \mathrm{MPa}$, which signifies fairly vast value ranges. However, after the comparison of the values of associated moduli related to different locations and various depth (see [4]), the examination of such a value range seemed reasonable for the different Kiscell clay samples,

- deformation modulus related to $50 \%$ of the final value of the deviatoric stress: $E_{50 \text { init }}=E_{\text {oed_init }}$ $=150 \div 250 \mathrm{MPa}$ and $E_{50}{ }^{\text {ref }}{ }_{-}{ }_{\text {init }}=E_{\text {oed }}{ }_{\text {ref }}{ }_{\text {init }}$ on the basis of the Plaxis 3D software and bibliographical references [5], as no laboratory test was performed for this modulus,

- unloading-reloading modulus: $E_{u r}{ }^{r e f}{ }_{\text {init }}=3 \div 5 \cdot E_{o e d}{ }^{\text {ref }}{ }_{\text {init, }}$, also on the basis of biographical recommendations [6] replacing the missing actual test results,

- cohesion: $\mathrm{c}=750 \div 1000 \mathrm{kPa}$ the range of values determined on the basis of the current triaxial tests,

- reference value of the initial shear modulus: $G_{0}{ }^{r e f}{ }_{i n i t}=200 \mathrm{MPa}$, which resulted from the comparison of the results of the $2 \mathrm{x}$ downhole measurements and the laboratory tests, which showed a significant deviation and also of the values that can be calculated by the formula recommended by Hardin and Black [7], 
- amount of the shear deformation for the modulus of $0.722 \cdot G_{0} \rightarrow \gamma_{0.7-7 i n i t}=7.5 \cdot 10^{-3}$ is the value estimated on the basis of the biography due to the uncertain results of the resonant column tests and the torsional shear tests,

- over-consolidation ratio: $\mathrm{OCR}=1.5 \div 4.5$ in the lack of direct laboratory measurements in accordance with related description in the previous section,

- interface parameter for the shaft: $R_{\text {inter }}^{s}=0.15 \div 0.30$ estimated range of values,

- interface parameter for the toe: $R_{\text {inter }}=0.80 \div 1.00$ estimated range of values.

The calculation of various modulus values for the $100 \mathrm{kPa}$ reference stress level used in Plaxis 3D was completed by the following formula:

$$
\mathrm{M}^{\mathrm{ref}}=\frac{\mathrm{M}}{\left(\frac{\mathrm{c} \cdot \cos \varphi+\sigma^{\prime} \cdot \sin \varphi}{\mathrm{c} \cdot \cos \varphi+\mathrm{p}^{\mathrm{ref}} \cdot \sin \varphi}\right)^{\mathrm{m}}}
$$

, where

- $M$ is the oedometric modulus ( $\left.E_{o e d}, E_{50}, E_{u r}\right)$ or the initial shear modulus $\left(G_{0}\right)$ in $\mathrm{kPa}$,

- $\quad c$ and $\varphi$ according to Tab 1 ,

- $\sigma$ is the $\sigma_{1}^{\prime}$ (effective vertical stress) for $E_{\text {oed }}$ or $\sigma_{3}^{\prime}$ (confining stress in triaxial test) for $E_{50}, E_{u r}, G_{0}$ in $\mathrm{kPa}$

- $\mathrm{p}^{\text {ref }}=100 \mathrm{kPa}$ is the reference confining pressure.

\section{RESULTS}

The final results of the modeling were represented by the curves produced for the bottom and top parts that were obtained by the systematic fine tuning of the model parameters of the Kiscell clay and their deviation in relation to the load test curves was the least. The deviation was measured by the method of the least squares. The minimization of the error function was realized on the basis of the following expression:

$$
\min \left[\sum_{i=1}^{16}\left(s_{m o_{i}}^{b}-s_{m e_{i}}^{b}\right)^{2}+\sum_{i=1}^{16}\left(s_{m o_{i}}^{S}-s_{m e_{i}}^{S}\right)^{2}\right]
$$

, where

- $s_{m o_{i}}^{b}$ the modelled displacement of the bottom section in the $\mathrm{i}^{\text {th }}$ load step,

- $s_{m e_{i}}^{b}$ the measured displacement of the bottom section in the $\mathrm{i}^{\text {th }}$ load step,

- $s_{m o_{i}}^{s}$ the modelled displacement of the top section in the $\mathrm{i}^{\text {th }}$ load step,

- $s_{m e_{i}}^{s}$ the measured displacement of the top section in the $\mathrm{i}^{\text {th }}$ load step.

- $i \quad$ the number of load steps (1-16).

During the modeling the values of the model parameters of the layers located above the Kiscell clay that had been assumed on the basis of the Soil Investigation Report were kept unchanged. It must be mentioned that the specific shaft resistances simulated by the above demonstrated a good match with the values of the load test. Although approximately half of the entire pile resistance was provided by the pile section that is in the grained layer, the parametrization is primarily focused on the Kiscell clay due to related research aspects of the CPRF structures designed to be installed in this layer. Apart from the fixed parameters of the Kiscell clay, by the fine 
tuning of the factors regarded as sensitive on the basis of the parameter test that cannot be outlined in detail due to lack of space, their values optimal from the aspect of the curve fitting were determined. These were the following: $E_{o e d}{ }^{r e f}, E_{50}{ }^{r e f}, E_{u r}{ }^{r e f}, c^{\prime}{ }_{r e f}, R_{\text {inter, }}^{s}, R_{\text {inter. }}^{t}$ When fitting the curve, the parameters of the numerical simulation were selected that provided the similarities in the nature and values of the model curves and pile load test curves with the least deviation. In this simulation the parameters of the Kiscell clay were provided with the values included in Table 2, this shall thus be regarded as the most appropriate group of HSS parameters on the basis of the simulation of the pile load test. In the Table, sublayers $a, b$ and $c$ of the clay layer divided due to the above-mentioned modeling technical reasons are included. The curves measured and obtained by the HSS model are represented in Figure 7. in which a curve achieved by the so-called Cemsolve calculation procedure is also demonstrated. This latter method was developed by a professional company specializing in O-cell pile load tests. Although the curve fit can be regarded as very good, the mobilization procedure of the specific shaft resistance of the Kiscell clay could not be modelled correspondently. A good correspondence in this aspect only resulted from the reproduction of the values obtained at the end of the load test with almost no deviation, by means of numeric simulation.

Tab. 2: Calibrated model parameters of Kiscell clay

\begin{tabular}{|c|c|c|c|c|c|c|c|c|c|c|}
\hline sub- & $E_{o e d}{ }^{\text {ref }}$ & Eur $_{\text {ref }}$ & $\mathrm{m}$ & $C^{\prime}$ ref & $\phi '$ & $\psi^{\prime}$ & $\gamma_{0,7}$ & $\mathrm{G}_{0}{ }^{\text {ref }}$ & $\mathrm{R}_{\text {inter }}$ & OCR \\
\hline layer & $\mathrm{kPa}$ & $\mathrm{kPa}$ & & $\mathrm{kPa}$ & $\circ$ & $\circ$ & - & $\mathrm{kPa}$ & - & - \\
\hline$a$ & 125.500 & 502.500 & \multirow{3}{*}{1,00} & \multirow{3}{*}{850} & \multirow{3}{*}{28} & \multirow{3}{*}{0} & \multirow{3}{*}{$7,5 \cdot 10^{-3}$} & \multirow{3}{*}{215.000} & 0,1400 & 3,5 \\
\hline$b$ & 118.000 & 472.000 & & & & & & & 0,1400 & 3,0 \\
\hline C & 109.000 & 437.000 & & & & & & & 0,8500 & 2,5 \\
\hline
\end{tabular}

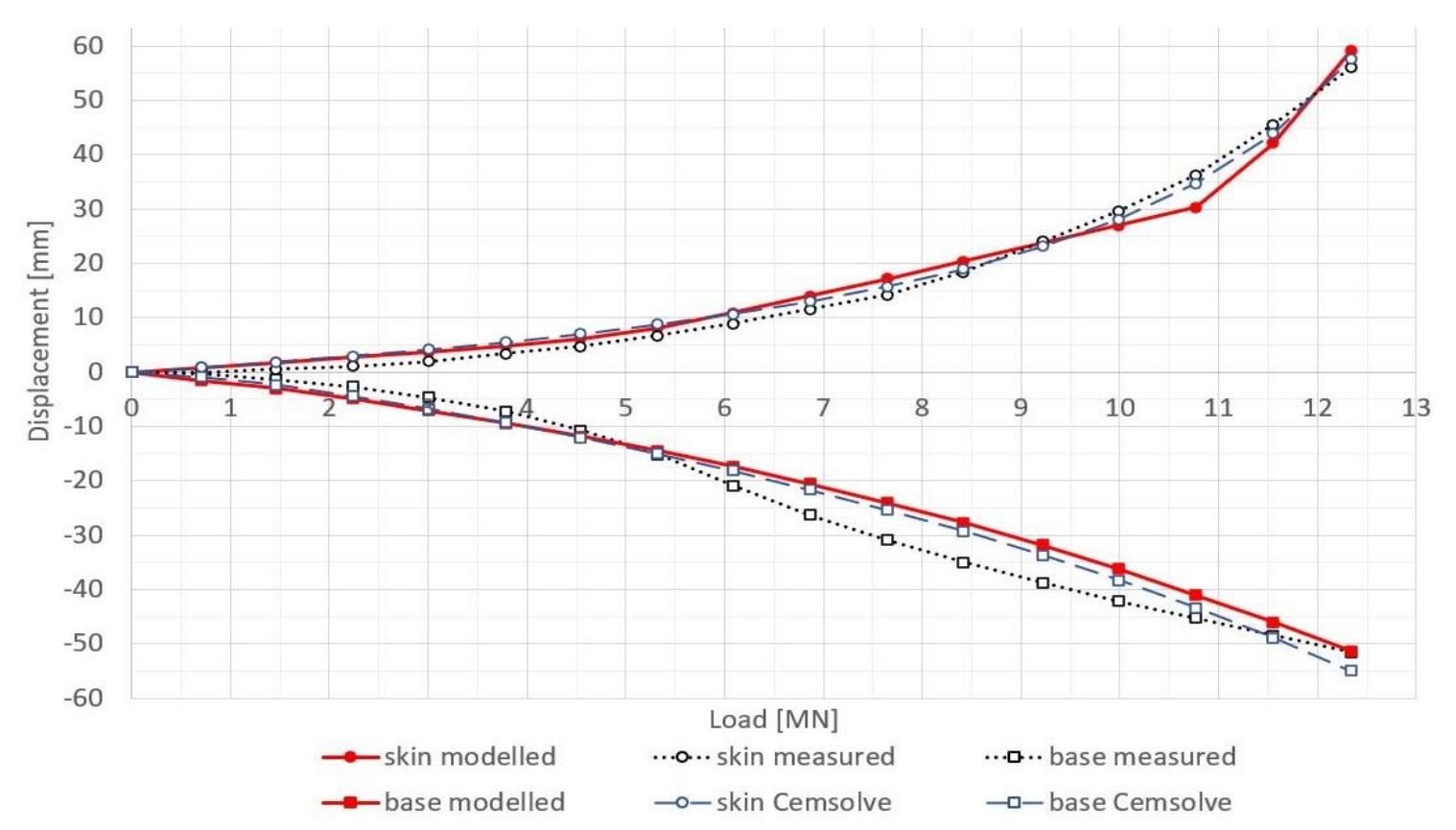

Fig. 7 - Modeled and measured load-displacement curves

It shall be mentioned that the simulation of the up to down loading was also realized using the model parameters included in Table 2, which cannot be published in the present article due to lack of space. It must also be noted that the self-anchoring, split pile so-called VUIS-pile load test can also be processed in a similar manner, a simpler attempt at which had previously been demonstrated by Szepesházi [8]. 


\section{CONCLUSION}

It results evident from the paper that by applying the HSS soil model with the Plaxis 3D software, if the model parameters are selected appropriately a real O-cell pile load test can be simulated correctly. It is also justified by the good correspondence of the load/displacement curves obtained for the bottom and top pile sections and the curves of measured values.

The article describes the HSS soil model parameters of the Kiscell clay settled as the deep soil environment of the test pile that are regarded as the most authentic on the basis of simulation, which in case of Kiscell clay soils of similar characteristics (typically located in Lágymányos and Kelenföld) might be used for their future modeling.

Although the Mohr-Coulomb soil model might also be suitable for the modeling of the stiff Kiscell clay that has rock-like characteristics, the HSS soil model promises to provide more precise results. One of its important advantages is the possibility of consideration of over-consolidation. On the basis of the parameter sensitivity test it might be stated that the OCR has a significant influence on the toe resistance. The issue of unloading-reloading modulus is related to over-consolidation, which has an essential role in all displacement calculations. On the basis of the simulation, it can be suggested that its value shall be 4 times the modulus related to the primary loading.

The article also demonstrates that for the modeling the Kiscell clay shall be divided into zones, especially due to the significant dependence of the OCR value on depth. It is also demanded by the fact that for the good modeling various $R_{\text {inter }}$ values shall be provided regarding the different structures and the interface elements of the pile shaft and toe.

The modeling techniques of the O-cell loading equipment that were presented and the processing based on the comparison of data measured and gained by simulation might - presumably - be applied for modeling other O-cell pile load tests. Besides the above, the results of the outlined pile load test can also be used in the modeling of the structural piles for the design of a traditional pile foundation or a CPRF structure.

\section{ACKNOWLEDGEMENTS}

The author would like to thank Dr. Szepesházi Róbert and Dr. Wolf Ákos for providing help and proof reading.

\section{REFERENCES}

[1] Hudacsek P., Kanizsár Sz., Koch E., Szepesházi R., Szilvágyi Zs., Wolf Á., 2020. A MOL Campus alapozásának vizsgálata (Analysis of Foundation of MOL Campus), In: Proceedings of the Geotechnika 2020 Conference, Herceghalom, Hungary, 12-14 October 2020, pp. 62-74.

[2] Tschuchnigg, F., 2012. 3D Finite Element Modeling of Deep Foundations Employing an Embedded Pile Formulation - Dissertation, Graz, pp. 162-168.

[3] Józsa V., 2016. Estimation and Separation of Pre-consolidation Stress Using Triaxial- and Oedometer Test in Kiscelli Clay, Periodica Polytechnica Civil Engineering, Vol. 60, No. 2, pp. 297-304. (DOI: 10.3311/PPci.9068)

[4] Görög P., 2007. Engineering geologic properties of the Oligocene Kiscell Clay, Central European Geology, Vol. 50, No. 4, pp. 313-329. (DOI:10.1556/CEuGeol.50.2007.4.2)

[5] Schanz, T., Vermeer, P.A., Bonnier, P.G., 1999. The hardening-soil model: Formulation and verification. In R.B.J. Brinkgreve, Beyond 2000 in Computational Geotechnics, Balkema, Rotterdam, pp. 281-290. (DOI:10.1201/9781315138206-27)

[6] R.B.J. Brinkgreve, W. Broere, 2004. Plaxis 3D Foundation Version 1., Part 3: Material Model Manual, Balkema, Rotterdam, pp. 1-1.

[7] Hardin, B.O., Black W.L., 1969. Vibration Modulus of Normally Consolidated Clay, Journal of the Soil Mechanics and Foundation Division, ASCE, Vol. 95, No. 6, pp. 1531-1537.

[8] Szepesházi R., Németh Gy., 2005. Az osztott cölöpös próbaterhelés feldolgozásának fejlesztése, Kutatási jelentés (Developing of the processing of split pile load test, Research Report), Széchenyi István Egyetem, Győr 